Article

\title{
Mineralogical and Geochemical Characteristics of Late Permian Coals from the Mahe Mine, Zhaotong Coalfield, Northeastern Yunnan, China
}

\author{
Xibo Wang *, Ruixue Wang, Qiang Wei, Peipei Wang and Jianpeng Wei \\ State Key Laboratory of Coal Resources and Safe Mining, China University of Mining and \\ Technology, Beijing 100083, China; E-Mails: wangruixue504@gmail.com (R.W.); \\ tonyweiq@gmail.com (Q.W.); wangpeipei1100@gmail.com (P.W.); \\ weijianpeng15@gmail.com (J.W.) \\ * Author to whom correspondence should be addressed; E-Mail: xibowang@gmail.com; \\ Tel./Fax: +86-10-6234-1868.
}

Academic Editor: Kota Hanumantha Rao

Received: 8 June 2015 / Accepted: 26 June 2015 / Published: 2 July 2015

\begin{abstract}
This paper reports the mineralogical and geochemical compositions of the Late Permian C2, C5a, C5b, C6a, and C6b semianthracite coals from the Mahe mine, northeastern Yunnan, China. Minerals in the coals are mainly made up of quartz, chamosite, kaolinite, mixed-layer illite/smectite (I/S), pyrite, and calcite; followed by anatase, dolomite, siderite, illite and marcasite. Similar to the Late Permian coals from eastern Yunnan, the authigenic quartz and chamosite were precipitated from the weathering solution of Emeishan basalt, while kaolinite and mixed-layer I/S occurring as lenses or thin beds were related to the weathering residual detrital of Emeishan basalt. However, the euhedral quartz and apatite particles in the Mahe coals were attributed to silicic-rock detrital input. It further indicates that there has been silicic igneous eruption in the northeastern Yunnan. Due to the silicic rock detrital input, the $\mathrm{Eu} / \mathrm{Eu}^{*}$ value of the Mahe coals is lower than that of the Late Permian coals from eastern Yunnan, where the detrital particles were mainly derived from the basalt. The high contents of Sc, V, Cr, Co, $\mathrm{Ni}, \mathrm{Cu}, \mathrm{Ga}$, and $\mathrm{Sn}$ in the Mahe coals were mainly derived from the Kangdian Upland.
\end{abstract}

Keywords: Late Permian coal; minerals; trace elements; Emeishan basalt/silicic rock; Mahe mine 


\section{Introduction}

Late Permian coals from the eastern Yunnan Province have recently attracted much attention, because of both the high female lung cancer rate caused by the indoor coal burning and the geological implication of mineral matter in the coals to the origin and evolution of Emeishan mantle plume. For the first aspect, Tian [1] and Tian et al. [2] found that the lung cancer risk was associated with crystalline silica released from the indoor coal burning. Dai et al. [3,4], Large et al. [5], and Wang et al. [6] observed high concentration of authigenic quartz (from nanometer to less than $20 \mu \mathrm{m}$ in size) in the Xuanwei coals. For the second aspect, Dai et al. [3,4,7], Zhou et al. [8], and Wang et al. [6] conducted a systematic mineralogical and geochemical study of the Late Permian coals and tonsteins from the southwest Chongqing and eastern Yunnan and suggested that, after massive flood basalt eruption, the magma evolved from mafic to silicic or alkalinity. The previous studies mostly focused on the coals in the eastern Yunnan, only Dai and Chou investigated mineral compositions in the coals from the northeastern Yunnan [9]. In this paper, we report the new data on the mineralogy and elemental geochemistry of the 5 coals in the Mahe mine, Zhaotong coalfield, northeastern Yunnan, China.

\section{Geological Setting}

The geological setting of the Late Permian coal basin from eastern Yunnan Province has been described in detail by several authors $[9,10]$. The Emeishan mantle plume uplift and extensive flood basalt eruption resulted in the formation of the Kangdian Upland [11,12]. Due to the existence of the Qinling sea trench to the north and Songpan basin to the west, the Kangdian Upland is the only possible source for the Xuanwei and Longtan/Changxing Formations in eastern Yunnan [12].
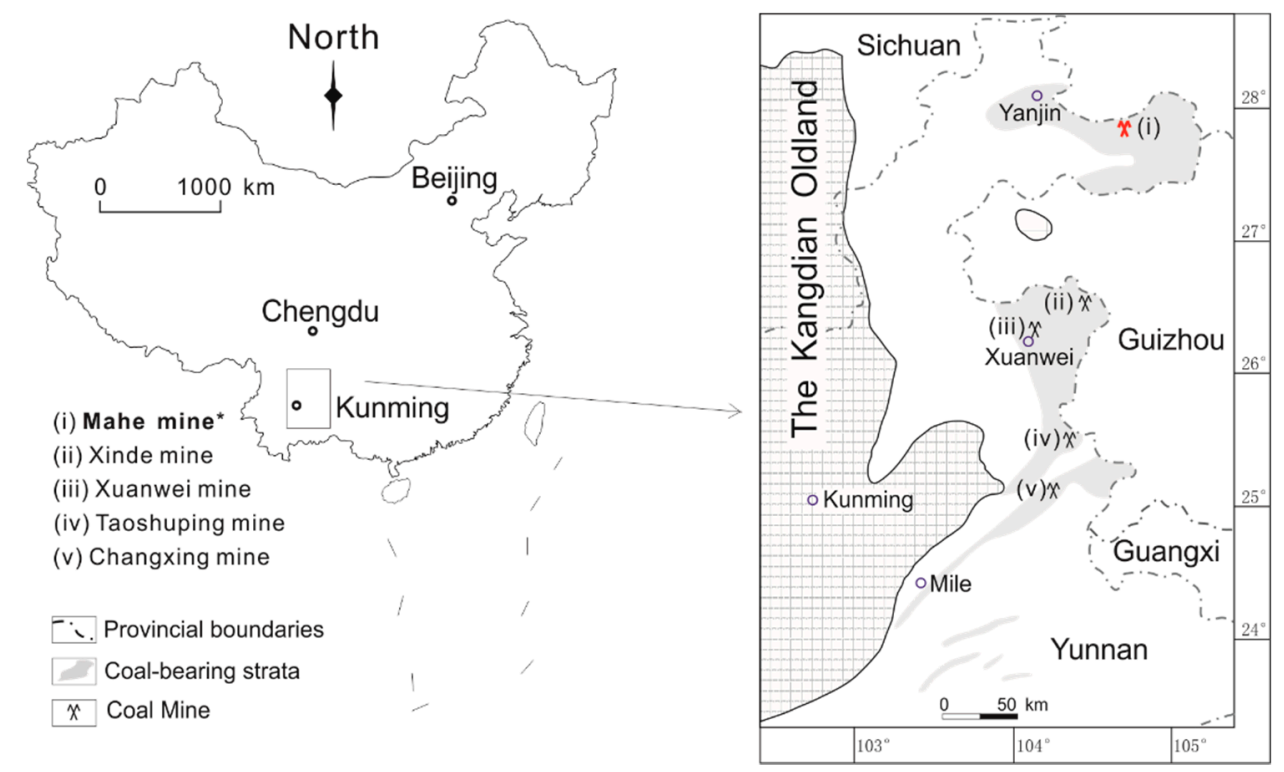

Figure 1. Location of the Mahe mine, Zhaotong coalfield, northeastern Yunnan Province, China, as well as locations of the Xinde, Xuanwei, Taoshuping, and Changxing mines, eastern Yunnan Province, China.

The Mahe mine from the Zhaotong coalfield is situated in the northeastern Yunnan Province (Figure 1). The coal-bearing strata are mainly the Changxing Formation and the Longtan Formation of Late 
Permian age. The Changxing Formation, with a thickness of $47 \mathrm{~m}$, is mainly made up of clastic sediments, including sandstone, mudstone, coal or limestone. It was deposited in a continent-marine transitional environment. There are four coal seams in Changxing Formation, named C1, C2, C3, and $\mathrm{C} 4$ in order from up to bottom, and most of them are too thin to be mined. The Longtan Formation has a thickness of $197 \mathrm{~m}$ and overlies the Middle Permian Xuanwuyan Formation (Figure 2). The Longtan Formation is comprised of mudstone, sandstone, gravel, and coal seams including $\mathrm{C} 5$, C6, and $\mathrm{C} 7$ coals. The No.5 coal is the major minable seam. Due to the less continuity of C6 and C7 coals in thickness, they could only be locally mined.

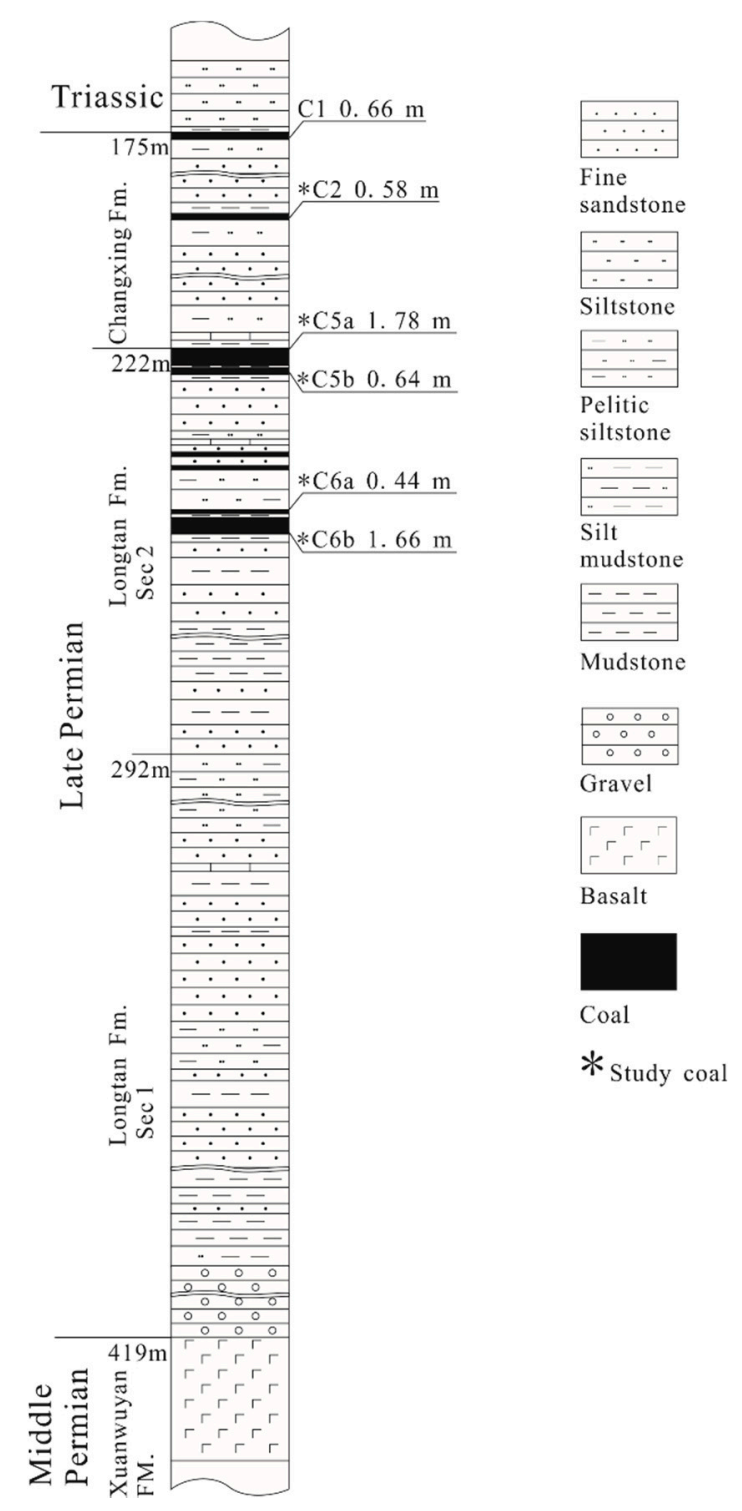

Figure 2. Stratigraphic column of the drill core from the Mahe mine, Zhaotong coalfield, northeastern Yunnan Province, China.

\section{Sample Collection and Methods}

The C5 and C6 coals in the Mahe mine are divided into two benches based on a stable parting, respectively. Thus, they were named as $\mathrm{C} 5 \mathrm{a}, \mathrm{C} 5 \mathrm{~b}, \mathrm{C} 6 \mathrm{a}$, and C6b, respectively. A total of five coal samples named MhC2 (0.78 m), MhC5a (1.78 m), MhC5b (0.64 m), MhC6a (0.44 m), and MhC6b (1.66 m) were 
collected from a drill core from the Mahe mine, northeastern Yunnan, China (Figures 1 and 2; Table 1). The coal samples were pulverized to $<1 \mathrm{~mm}$ fractions by hammer for briquette preparation.

Table 1. Random vitrinite reflectance, proximate analyses, and total sulfur in coals from the Mahe mine (\%).

\begin{tabular}{cccccc}
\hline Samples & $\boldsymbol{M}_{\text {ad }}$ & $\boldsymbol{A}_{\mathbf{d}}$ & $\boldsymbol{V}_{\text {daf }}$ & $\boldsymbol{R}_{\mathbf{0}, \text { ran }}$ & $\boldsymbol{S}_{\mathbf{t , d}}$ \\
\hline MhC2 & 0.97 & 42.24 & 14.82 & 2.21 & 3.17 \\
MhC5a & 0.7 & 25.75 & 12.86 & 2.27 & 2.31 \\
MhC5b & 0.96 & 33.67 & 13.83 & 2.24 & 3.86 \\
MhC6a & 0.7 & 36.72 & 16.29 & 2.45 & 2.45 \\
MhC6b & 0.66 & 29.62 & 13.67 & 2.31 & 2.49 \\
Average & 0.80 & 33.60 & 14.29 & 2.30 & 2.86 \\
Maximum & 0.97 & 42.24 & 16.29 & 2.45 & 3.86 \\
Minimum & 0.66 & 25.75 & 12.86 & 2.21 & 2.31 \\
\hline
\end{tabular}

$R_{\mathrm{o}, \text { ran, }}$, random vitrinite reflectance; $M$, moisture; $A$, ash yield; $V$, volatile matter; $S_{\mathrm{t}}$, total sulfur; ad, air-dry basis; d, dry basis; daf, dry and ash-free basis

Proximate analysis, covering moisture, volatile matter, and ash yield, was measured following the ASTMD3173-11 [13], ASTM D3175-11 [14], and ASTMD3174-11 [15], respectively. Total sulfur was determined in accordance with ASTMD 3177-02 [16]. Mean random vitrinite reflectance were measured using a Leica DM 4500P microscopy (Leica, Wetzlar, Germany) (at a magnification of 500×) equipped with a Craic QDI 302TM spectrophotometer (Craic, San Dimas, CA, USA). The standard reference for vitrinite reflectance measurement was gadolinium gallium garnet (Klein and Becker, Idar-Oberstein, Germany) with a calculated standard reflectance of $1.722 \%$ for $\lambda=546 \mathrm{~nm}$ under oil immersion.

Mineral phases were investigated in coal briquette by optical microscopy and by a scanning electron microscope equipped with an Oxford energy-dispersive X-ray spectrometer (SEM-EDX, Hitachi, Tokyo, Japan), confirmed by X-ray diffraction (XRD, D/max 2500, Rigaku, Tokyo, Japan) on low-temperature ashes of coal (LTA). Low-temperature ashes of coal was performed using an EMITECH K1050 Plasma Asher (Quorum, Lewes, UK). XRD analysis of low temperature ashes was performed on a powder diffractometer with a Ni-filtered $\mathrm{Cu}-\mathrm{K} \alpha$ radiation with a scintillation detector. The XRD pattern was recorded over a $2 \theta$ interval of $2.6^{\circ}-70^{\circ}$, with a step size of $0.02^{\circ}$, and a $0.3 \mathrm{~mm}$ receiving slit. The X-ray diffractograms of LTAs of five coal samples were subjected to quantitative mineralogical analysis using Siroquant ${ }^{\mathrm{TM}}$ (Sietronics, Mitchell, Australia). Further details demonstrating the use of this technique for coal-related materials are given by Ward et al. $[17,18]$ and Ruan and Ward [19].

Samples were crushed and ground by a shatterbox to pass 200 mesh for geochemical analysis. X-ray fluorescence (XRF) spectrometry (ARL Advant'XP+, ThermoFisher, Waltham, MA, USA) was used to determine the major element oxides including $\mathrm{Al}_{2} \mathrm{O}_{3}, \mathrm{SiO}_{2}, \mathrm{Fe}_{2} \mathrm{O}_{3}, \mathrm{CaO}, \mathrm{Na}_{2} \mathrm{O}, \mathrm{MgO}, \mathrm{K}_{2} \mathrm{O}$, $\mathrm{TiO}_{2}, \mathrm{P}_{2} \mathrm{O}_{5}$, and $\mathrm{MnO}$ as outlined by Dai et al. [20]. Inductively coupled plasma mass spectrometry (X series II ICP-MS, ThermoFisher) was used to determine elements in coal samples as outlined by Dai et al. [7], except for Hg and F. Mercury was determined by DMA-80 (Milestone, Sorisole, Italy) in which samples are heated and the evolved $\mathrm{Hg}$ is selectively captured as an amalgam and measured by 
atomic absorption spectrophotometry. The detection limit of $\mathrm{Hg}$ is $0.005 \mathrm{ng}$, the relative standard deviation (RSD) from eleven runs on $\mathrm{Hg}$ standard reference is $1.5 \%$, and the linearity of the calibration is in the range $0-1000 \mathrm{ng}$ [21]. Fluorine was determined by the ion-selective electrode method (ISE) following the procedures described in ASTM method D5987-96 [22]. For quality control in fluorine determination, the standard reference materials GBW 11121 and GBW 11123 were analyzed with each batch of samples.

\section{Results}

\subsection{Coal Chemistry}

Table 1 lists the data of chemical analysis (including proximate analysis, and total sulfur), and random vitrinite reflectance. Based on ASTM standard D388-12 [23], the five Mahe coals are semianthracite in rank, with an average volatile yield of $14.29 \%$ (ranging from $12.86 \%$ to $16.29 \%$ ) on the ash free basis and an average random vitrinite reflectance of $2.30 \%$ (ranging from $2.21 \%$ to $2.45 \%$ ). The Mahe coals have moisture of $0.66 \%$ to $0.97 \%$ (average $0.80 \%$ ), ash yield of $25.75 \%$ to $42.24 \%$ (average $33.60 \%$ ), and total sulfur of $2.31 \%$ to $3.86 \%$ (average $2.86 \%$ ).

The $\mathrm{C} 5 \mathrm{a}$ and $\mathrm{C} 6 \mathrm{~b}$ seams are classified as medium-ash coal, the $\mathrm{C} 5 \mathrm{~b}$ and C6a seams are medium-high-ash coal, and the $\mathrm{C} 2$ seam is high-ash coal according to Chinese Standards GB/T 15224.1-2010 [24]; coals with ash yield 20.01\%-30.00\% are medium-ash coals, coals with ash yield $30.01 \%-40.00 \%$ are medium-high-ash coals, and coals with $40.01 \%-50.00 \%$ ash are high-ash coals. The C5a, C6a, and C6b seam are medium-high sulfur $(2.01 \%-3.00 \%)$ coals, while the $\mathrm{C} 2$ and C5b seams are high-sulfur (>3.00\%) coals according to Chinese Standards GB/T 15224.2-2010 [25].

The rank of Late Permian coal from eastern Yunnan is different from that of northeastern area. The coals from the northeastern Zhaotong coalfield (155 channel samples) are mainly semiathracite $\left(R_{\mathrm{o}, \text { ran }}=1.98 \%-2.52 \%\right.$, mean $2.25 \% ; V_{\mathrm{daf}}=7.64 \%-20.6 \%$, mean $\left.11.9 \%\right)$ [9]. The Mahe coals are also mainly semianthracite. However, the coals from eastern Yunnan are mainly medium volatile bituminous, such as the Xinde coals $\left(R_{o, \text { ran }}=1.21 \%-1.23 \%, V_{\text {daf }}=25.69 \%-26.74 \%\right)$ [4], the Xuanwei coals $\left(V_{\mathrm{daf}}=27.1 \%-32.68 \%\right)[3]$, and the Taoshuping coals $\left(R_{\mathrm{o}, \text { ran }}=0.94 \%-1.37 \%, V_{\mathrm{daf}}=23 \%-29.3 \%\right)[6]$. Different from the most Late Permian coals from eastern Yunnan, the Changxing coals are high in rank, which is semianthracite $\left(R_{\mathrm{o}, \text { ran }}=2.46 \%-2.63 \%, V_{\mathrm{daf}}=7 \%-11.48 \%\right)$ [26]. Metamorphism of the Late Permian coals in eastern Yunnan is mainly attributed to the burial geothermal gradient. For example, in the Taoshuping profile the decreasing trend of volatile yield is coupled with random vitrinite reflectance increasing with increasing depth [6]. However, the elevated rank of the Changxing coal was related to the thermal alteration induced by the igneous intrusion [26]. No massive igneous intrusion was observed in the Zhaotong coalfield in the previous study by Dai and Chou [9] and the present study as discussed below, it is inferred the metamorphism of Zhaotong coals mainly resulted from a burial geothermal gradient which is higher than that of Taoshuping mine.

\subsection{Minerals in the Mahe Coals}

Minerals in the Mahe coals were observed by optical microscopy and SEM-EDX, confirmed by LTA + XRD. The quantitative XRD results from siroquant ${ }^{\mathrm{TM}}$ show that minerals in the Mahe coals are 
mainly comprised of quartz, chamosite, kaolinite, mixed-layer I/S, pyrite, and calcite, and followed by anatase, dolomite, siderite, illite and marcasite (Table 2).

Table 2. Mineral compositions of low-temperature ashes (LTA) of the Mahe coals by XRD analysis and Siroquant (\%; on organic matter-free basis).

\begin{tabular}{cccccccccccc}
\hline Samples & Qu & Ana & Cal & Dol & Sid & Py & Mar & Kao & Cha & Illite & I/S \\
\hline Mh C2 & 43.4 & - & 21 & - & 1.2 & 8.2 & - & - & 14.4 & 6.8 & 5 \\
Mh C5a & 49.2 & - & 8 & 1.3 & - & - & - & 26.6 & 12.9 & - & 2.1 \\
Mh C5b & 50.4 & 4.9 & 11.1 & - & - & 10.2 & - & 13.6 & 2.3 & - & 7.5 \\
Mh C6a & 8.9 & 4.5 & 5.1 & 6.1 & 0.6 & 5.5 & 3.4 & 54 & 8.6 & - & 3.3 \\
Mh C6b & 27.8 & - & 4.9 & - & 1 & 10 & 3.3 & 36.6 & 13.8 & - & 2.7 \\
\hline
\end{tabular}

Qu, quartz; Ana, Anatase; Cal, Calcite; Dol, Dolomite; Sid, Siderite; Py, Pyrite; Mar, Marcasite; Kao, Kaolinite; Cha, Chamosite; I/S, mixed-layer illite/smectite (I/S).

Quartz is the most common mineral in coal. Its concentration in the LTA of the Mahe coals varies from $8.9 \%$ to $50.4 \%$, with an average of $38.2 \%$ (Table 2). Quartz in the Mahe coals has two origins: (i) authigenic and (ii) terrigenous or silicic volcanic ashes. The authigenic quartz is mainly present as disseminated irregular particles distributed in collodetrinite (Figure 3A), and is usually less than $20 \mu \mathrm{m}$ in size. The microscopy observation shows that the authigenic quartz accounts for more than $90 \%$ of the total quartz. However, quartz of terrigenous origin, preserving well edges and angles and a completely euhedral crystal form (Figure 3B), occurs mainly as assemblages or discrete particles. It is larger in size $(100$ to $500 \mu \mathrm{m})$ than the authigenic quartz (Figure 3A) and the quartz of volcanic origin (20 to $100 \mu \mathrm{m}$ ) (Figure 3C). Based on the modes of occurrences, it is suggested that the source area of the terrigenous quartz is not far from the peat mire, because the frequently collision and friction suffered from a long distance transport would have resulted in a more rounded shape. $\beta$-form quartz is common in the Late Permian coals from eastern Yunnan, indicating a silicic volcanic ashes input $[3,4,6]$. This is also the case in the Mahe coal samples. The $\beta$-form quartz in the Mahe coals is similar in shape and size with that in the Xinde and Taoshuping coals $[3,6]$. It has a typical hexagonal form and a small size (less than $100 \mu \mathrm{m}$ ), and some of them occur as a doubly terminated bipyramidal form with an additional prism face (Figure 3C). Compared with common silicic volcanic ashes input indicated by the $\beta$-form quartz in the eastern Yunnan, mafic volcanic ashes input was only identified in the $\mathrm{k} 21 \mathrm{~b}$ coal from the Taoshuping mine [6].

Although chlorite is not common in coals [27], it was also observed in some high rank coals and formed by epigenetic processes [28,29]. Mixed-layer I/S in coal could be altered to chlorite [27,30,31]. Chamosite $\left[\mathrm{Fe}_{3}{ }^{2+} \mathrm{Mg}_{1.5} \mathrm{AlFe}_{0.5}{ }^{3+} \mathrm{Si}_{3} \mathrm{AlO}_{12}(\mathrm{OH})_{6}\right]$, a type of chlorite, is common in the Late Permian coals of eastern Yunnan [3,4,6,9]. Chamosite is also present in all the Mahe coal samples (Figure 4), with a concentration from $2.3 \%$ to $14.4 \%$ (average $10.4 \%$ ) (Table 2). The chamosite occurs mainly as cell-infillings alone (Figure 3D), sometimes exists with quartz and/or calcite. The coexisting of authigenic quartz and chamosite in the coals were mainly precipitated from the Fe-Mg-rich siliceous solution derived from the weathering of basalt, similar to the mechanism reported by Dai et al. [3] and Wang et al. [6]. Dai and Chou [9] has shown that some chamosite is closely related to quartz and kaolinite in the Zhaotong coals, and was suggested to be derived from the interaction of kaolinite with $\mathrm{Fe}-\mathrm{Mg}$ rich fluids during early diagenesis. 

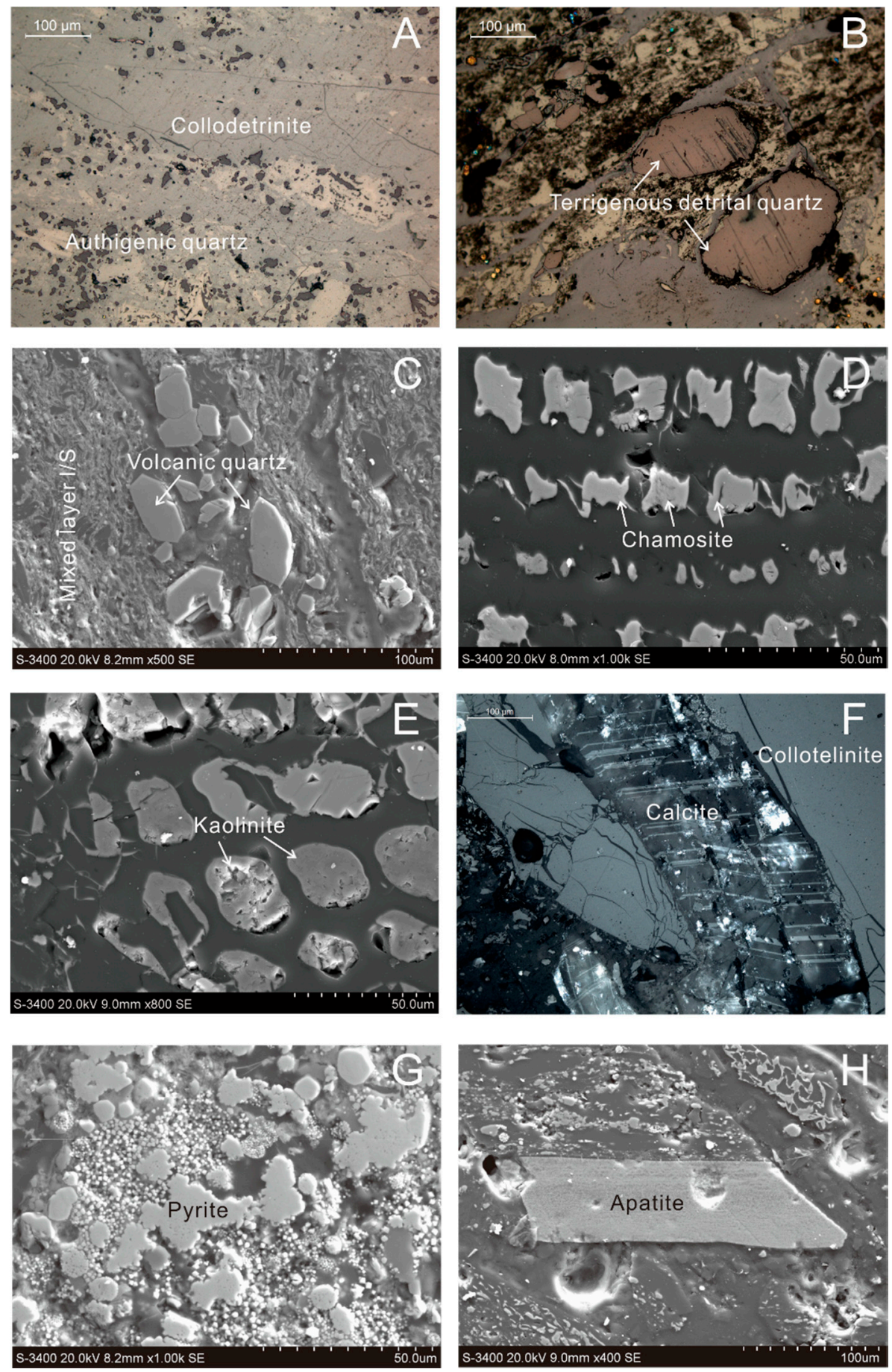

Figure 3. Minerals in the Mahe coals. (A) Disseminated irregular quartz particles in collodetrinite in the sample $\mathrm{MhC} 2$ (reflected light); (B) euhedral quartz in the sample MhC2 (reflected light); (C) $\beta$-form quartz of silicic volcanic ashes origin in the sample MhC2 (SEM, secondary electron image); (D) chamosite as cell-infillings in the sample MhC2 (SEM, secondary electron image); (E) kaolinite as cell-infillings in the sample MhC5a (SEM, secondary electron image); (F) calcite veins in the fractures of collotelinite with the twin-striation characteristics under crossed polarized light in the sample MhC2 (reflected light, oil immersion); (G) pyrite as disseminated or framboidal particles in the sample MhC2 (SEM, secondary electron image); $(\mathbf{H})$ euhedral apatite in the sample MhC2 (SEM, secondary electron image). 


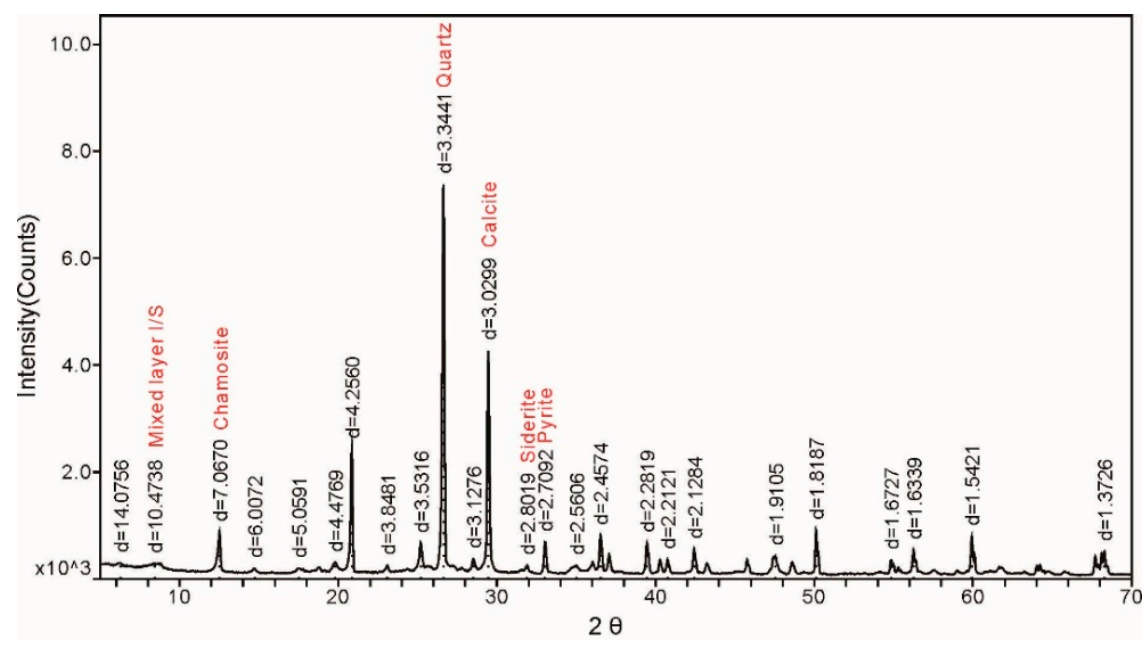

Figure 4. Identification of minerals in the XRD pattern of the low temperature ashes (LTA) of the MhC2.

Kaolinite and mixed-layer I/S are common in coal [32,33]. Kaolinite was identified in the LTA of the samples MhC5a, MhC5b, MhC6a, and MhC6b, with concentrations of 26.6\%, 13.6\%, 54\%, and $36.6 \%$, respectively (Table 2). Kaolinite in the sample MhC2 is below detection limit of XRD and Siroquant. Mixed-layer I/S is present in all the LTA of the coal samples, ranging from $2.1 \%$ to $7.5 \%$ (average 4.1\%), and much lower than those of kaolinite and chamosite (Table 2). Illite is only detected in the MhC2 sample. Kaolinite and mixed-layer I/S in the Mahe coals occur mainly as recrystallization particles, lenses, and thin beds, indicating a terrigenous origin. The kaolinite and mixed-layer I/S were derived from the weathering products of basalt from the Kangdian Upland [6,9]. In addition, kaolinite as infillings of cells or fractures (Figure 3E) is similar to that in the Xinde coals, suggesting a authigenic origin [4]. Mixed-layer I/S in the Changxing coals occurs not only as lenses or thin beds but also as infillings of maceral fractures. The mixed-layer infillings of fractures is of epigenetic origin and precipitated from hydrothermal fluids of a igneous intrusion [6].

Calcite is common carbonate in the Late Permian coals from eastern Yunnan. It occurs mainly as fracture/pores infillings, indicating an epigenetic origin of hydrothermal fluids [3,4,9]. Although detrital calcite is very rare in coal because calcite can be easily-decomposed under acid conditions in the peat bog; however, syngenetic deposition of calcite (aragonite) is possible if a sediment source region mainly made up of carbonate rocks is located close to the peat mire [34,35]. Detrital calcite was identified in the Taoshuping coals [6]. The detrital calcite was probably blown by winds to the peat mire from the limestone of Middle Permian Maokou Formation [6], which underlies below the Xuanwuyan Formation. The content of calcite in the LTA of the Mahe coals varies from $4.9 \%$ to $21 \%$ (average 10\%) (Table 2). It is mainly present as veins in macerals and display twin-striation characteristics under crossed polarized light (Figure 3F). In some cases, calcite fills the cells with quartz and/or chamosite.

Pyrite in the Mahe coals is dominated by disseminated fine or framboidal particles in macerals, and followed by massive particles of several micrometers in size (Figure 3G). Their modes of occurrences suggest a syngenetic origin [36].

Due to its low concentration, apatite was below the detection limit of XRD technique. It was only observed in the sample MhC2 under SEM-EDX. The apatite preserved distinct edges and angles, and 
has a big size of $220 \mu \mathrm{m}$ in length and $60 \mu \mathrm{m}$ in width (Figure $3 \mathrm{H}$ ). However, apatite of silicic volcanic ashes origin in the Taoshuping coals is less than $5 \mu \mathrm{m}$ in size [6].

\subsection{Major and Trace Elements}

\subsubsection{Major Elements}

As compared with Chinese average coals [37], the mean concentrations of major element oxides including $\mathrm{SiO}_{2}$ (17.31\%), $\mathrm{Al}_{2} \mathrm{O}_{3}$ (8.26\%), $\mathrm{CaO}$ (1.57\%), $\mathrm{K}_{2} \mathrm{O}(0.32 \%), \mathrm{MnO}(0.03 \%)$, and $\mathrm{TiO}_{2}(0.50 \%)$ are enriched with concentration coefficients $(\mathrm{CC}$, the ratio of the average elements concentration of the Mahe coals to that of Chinese average coals) of 2.04, 1.38, 1.28, 1.68, 1.50, and 1.52, respectively (Table 3). However, the mean concentrations of $\mathrm{Fe}_{2} \mathrm{O}_{3}(3.4 \%), \mathrm{MgO}(0.21 \%), \mathrm{Na}_{2} \mathrm{O}(0.14 \%)$, and $\mathrm{P}_{2} \mathrm{O}_{5}$ $(0.07 \%)$ are lower than or close to that of Chinese average coals [37].

The ratio of $\mathrm{SiO}_{2} / \mathrm{Al}_{2} \mathrm{O}_{3}$ in the Mahe mine ranges from 1.57 to 4.49 , with an average of 2.24. It is much higher than that of Chinese average coals 1.42 [37] and the theoretic value of kaolinite (1.18). The higher value of $\mathrm{SiO}_{2} / \mathrm{Al}_{2} \mathrm{O}_{3}$ is attributed to the presence of abundant authigenic quartz. The $\mathrm{CaO}$ has a content of $0.61 \%$ to $3.14 \%$, and the $\mathrm{MnO}$ has a content of $0.01 \%$ to $0.07 \%$. $\mathrm{CaO}$ in the coals is mainly related to veins of calcite (Figure 3F). The significant relation coefficient between $\mathrm{CaO}$ and $\mathrm{MnO}(0.88)$ supports that they have a similar mode of occurrence. The concentration of $\mathrm{Fe}_{2} \mathrm{O}_{3}$ varies from $2.3 \%$ to $5.37 \%$, with an average of $3.4 \%$. The low positive relation coefficient between $\mathrm{Fe}_{2} \mathrm{O}_{3}$ and $S_{\mathrm{p}, \mathrm{d}}\left(r_{\mathrm{Fe}_{2} O_{3}-S_{p, d}}=0.61\right)$ suggest that $\mathrm{Fe}$ is not only associated with pyrite, but also associated with chamosite. The average contents of $\mathrm{K}_{2} \mathrm{O}$ and $\mathrm{Na}_{2} \mathrm{O}$ are $0.32 \%$ and $0.14 \%$, respectively. $\mathrm{K}_{2} \mathrm{O}$ and $\mathrm{Na}_{2} \mathrm{O}$ are probably attributed to mixed-layer I/S, and illite. Anatase is primarily responsible for $\mathrm{TiO}_{2}$ in the Mahe coals.

\subsubsection{Trace Elements}

As compared with Chinese average coals [37], the Mahe coals are high in Sc (4.38 $\mu \mathrm{g} / \mathrm{g})$, $\mathrm{V}(105 \mu \mathrm{g} / \mathrm{g}), \mathrm{Cr}(45.7 \mu \mathrm{g} / \mathrm{g})$, Co $(19.0 \mu \mathrm{g} / \mathrm{g}), \mathrm{Ni}(29.8 \mu \mathrm{g} / \mathrm{g}), \mathrm{Cu}(70.4 \mu \mathrm{g} / \mathrm{g}), \mathrm{Ga}(14.9 \mu \mathrm{g} / \mathrm{g})$, and Sn $(4.75 \mu \mathrm{g} / \mathrm{g})$, with a concentration coefficient (CC) higher than 2 (Table 3). This is similar to the Late Permian coals from Taoshuping [6], Xinde [4], and Changxing [27], Xuanwei [3] mines, eastern Yunnan. The high concentrations of Sc, V, Cr, Co, and Ni in the Mahe coals are mainly attributed to the Emeishan basalt from Kangdian Upland, which is located to west of the basin and is the only source region of the Late Permian coals in eastern Yunnan [10]. The Emeishan basalt is high in Sc $(29.8 \mu \mathrm{g} / \mathrm{g}), \mathrm{V}(317 \mu \mathrm{g} / \mathrm{g}), \mathrm{Cr}(176 \mu \mathrm{g} / \mathrm{g}), \mathrm{Co}(43.1 \mu \mathrm{g} / \mathrm{g})$, and Ni $(104 \mu \mathrm{g} / \mathrm{g})$ [38].

Although the average contents of potentially toxic elements $\mathrm{F}$ and $\mathrm{Hg}$ are lower than that of Chinese average coals [37], they are enriched in some coal samples. The MhC2 has a $246 \mu \mathrm{g} / \mathrm{g}$ fluorine, which is probably related to the P-bearing mineral apatite (Figure $3 \mathrm{H}$ ). Fluorine in the Taoshuping coals also shows a significant positive relationship with phosphorous [6]. Mercury in the Mahe coals varies from 254 to $320 \mathrm{ng} / \mathrm{g}$ (average $277 \mathrm{ng} / \mathrm{g}$ ), which is much higher than that of the Xinde coals (average $44 \mathrm{ng} / \mathrm{g}$ ). Because mercury in coal is usually related to sulfur-bearing minerals [39-41], the high total sulfur of Mahe coals $\left(S_{\mathrm{t}, \mathrm{d}}=2.86 \%\right.$, Table 1$)$ is probably responsible for the elevated $\mathrm{Hg}$, while the total sulfur of Xinde coal is only $0.16 \%$ [4]. 
Table 3. Contents of oxides of major elements and trace elements in the Mahe coals from northeastern Yunnan, China (in $\mu \mathrm{g} / \mathrm{g}$ unless as indicated).

\begin{tabular}{|c|c|c|c|c|c|c|c|c|c|c|c|c|c|c|c|c|c|c|}
\hline Samples & $\mathrm{SiO}_{2}$ & $\mathbf{A l}_{2} \mathbf{O}_{3}$ & $\mathrm{CaO}$ & $\mathrm{Fe}_{2} \mathrm{O}_{3}$ & $\mathbf{K}_{2} \mathbf{O}$ & MgO & MnO & $\mathrm{Na}_{2} \mathrm{O}$ & $\mathbf{P}_{2} \mathbf{O}_{5}$ & $\mathrm{TiO}_{2}$ & $\mathbf{L i}$ & $\mathrm{Be}$ & $\mathbf{F}$ & Sc & V & $\mathrm{Cr}$ & Co & $\mathbf{N i}$ \\
\hline & 22.92 & 511 & & 5.37 & 0.68 & 0.48 & 007 & 0.08 & & 0.23 & 17.5 & & & & & 31.5 & 14.1 & 29.1 \\
\hline & 13 & & & & & & & & & & 26.8 & & 79 & 2.9 & 20.8 & 18 & 12 & 5.9 \\
\hline & & & & & & & & 0.2 & & 0.76 & 23 & 0.93 & 77 & & 67.5 & & & 20.4 \\
\hline MhC6a & 17.56 & 13.53 & & & & & & & & 0.84 & 45.2 & 2.66 & 104 & 3.3 & 182 & 68.4 & 7.5 & 37 \\
\hline MhC6b & 14.78 & 9.39 & 61 & 3.04 & & & 0.01 & & & & 30 & 2.01 & 68 & 13.3 & 139 & 55.4 & 28.9 & 46.5 \\
\hline Average $^{a}$ & 17.31 & 8.26 & 57 & 3.40 & 0.32 & 0.21 & 0.03 & 0.14 & 0.07 & 0.50 & 28.50 & 1.59 & 115 & 8.96 & 105 & 45.66 & 18.96 & 29.78 \\
\hline Coal $^{\mathrm{b}}$ & 8.47 & 5.98 & 1.23 & 4.85 & 0.19 & 0.22 & 0.02 & 0.16 & 0.09 & 0.33 & 31.8 & 2.11 & 130 & 4.38 & 35.1 & 15.4 & 7.08 & 13.7 \\
\hline $\mathrm{CC}^{\mathrm{c}}$ & 2.04 & 1.38 & 1.28 & 0.70 & 1.68 & 0.97 & 1.50 & 0.90 & 0.76 & 1.52 & 0.90 & 0.75 & 0.88 & 2.05 & 2.99 & 2.96 & 2.68 & 2.17 \\
\hline Samples & $\mathbf{C u}$ & & & & & & $\mathbf{Y}$ & $\mathbf{Z r}$ & & & & & Cs & & La & $\mathrm{Ce}$ & $\operatorname{Pr}$ & Nd \\
\hline & 80.1 & & & 2.0 & 30 & 13 & 27.2 & 77.6 & & 2.95 & 3.43 & 0.37 & 1.95 & 87.2 & 35.3 & 70.6 & & 40.5 \\
\hline MhC5a & 18.2 & & & & 3.9 & 11 & & & & & & & 0.4 & & 6.1 & 31.8 & .76 & 13.9 \\
\hline & 45.5 & 32.2 & 10.4 & & 15 & 94 & 16 & 120 & & 1. & 4.55 & & 0.66 & & 23.3 & 46.8 & 5.48 & 20.3 \\
\hline & 124 & & 24.3 & & 12.7 & 87.8 & & & & 1.36 & 7.1 & 0.82 & 1.45 & .7 & 69.5 & 133 & & 62.9 \\
\hline $\mathrm{MhC}$ & & & & & & & & & & & & & 0.85 & & & 126 & & 59.9 \\
\hline Average $^{\mathrm{a}}$ & 70.40 & 35.94 & 14.90 & 2.20 & 14.18 & 99.86 & 31.58 & 112 & 12.40 & 1.64 & 4.75 & 0.56 & 1.06 & 64.52 & 41.18 & 81.64 & 10.00 & 39.50 \\
\hline Coal $^{\mathrm{b}}$ & 17.5 & & & & & & & & & & 2.11 & & 1.13 & & & 46.7 & 6.42 & 22.3 \\
\hline & 4.02 & & & 0.79 & & 0.71 & & & & 0.53 & 2.25 & 0.67 & 0.94 & 0.41 & 1.83 & 1.75 & 1.56 & 1.77 \\
\hline Samples & Sm & & & $\mathbf{T b}$ & & & & & $\mathbf{Y b}$ & & Hf & Ta & $\mathrm{Hg}^{\mathrm{d}}$ & TI & $\mathbf{P b}$ & $\mathbf{B i}$ & Th & $\mathbf{U}$ \\
\hline $\mathrm{MhC2}$ & 7.95 & & & 1.09 & & 0.9 & 2.4 & & 2.15 & 0.34 & 3.44 & 0.44 & 258 & 0.9 & 9.76 & 0.17 & 4.72 & 3.28 \\
\hline & & & & & & & & & & & 2.49 & & 254 & & & 0.21 & 5.2 & 1.49 \\
\hline $\mathrm{MhC} 5 \mathrm{~b}$ & 3.59 & & & & & & & & & & & & 320 & & & & .56 & 1.37 \\
\hline MhC6a & 9.24 & 1.73 & 7.73 & 1.28 & 7.23 & 1.35 & 4.25 & 0.6 & 4.03 & 0.63 & 8.99 & 1.57 & 264 & 0.17 & 20.4 & 0.34 & 11.1 & 2.84 \\
\hline & 10.1 & & & & 9.59 & 1.82 & 5.53 & & & 0.71 & 5.46 & 0.97 & 289 & 0.21 & 34.7 & 0.28 & 7.73 & 2.1 \\
\hline Average $^{a}$ & 6.74 & 1.32 & 6.19 & 1.00 & 5.63 & 1.06 & 3.19 & 0.45 & 2.96 & 0.44 & 5.10 & 0.89 & 277 & 0.31 & 16.76 & 0.24 & 7.06 & 2.22 \\
\hline $\mathrm{Coal}^{\mathrm{b}}$ & 4.07 & & .65 & 0.62 & 3.74 & 0.96 & 1.79 & 0.64 & 2.08 & 0.38 & 3.71 & 0.62 & 163 & 0.47 & 15.1 & 0.79 & 5.84 & 2.43 \\
\hline $\mathrm{CC}^{\mathrm{c}}$ & 1.66 & 1.57 & 1.33 & 1.62 & 1.51 & 1.10 & 1.78 & 0.71 & 1.42 & 1.16 & 1.37 & 1.44 & 1.70 & 0.66 & 1.11 & 0.30 & 1.21 & 0.91 \\
\hline
\end{tabular}

a, Average, arithmetic mean; b, Coal, Chinese average coals value by Dai et al. [37]; c, CC, the ratio of average elements in the Mahe coals to Chinese average coals [37]; d, Hg in $\mathrm{ng} / \mathrm{g}$. 


\subsubsection{Rare Earth Elements and Yttrium (REY)}

A three-fold classification of rare earth elements and yttrium (REY) was used for this study: light (LREY: La, Ce, Pr, Nd, and Sm), medium (MREY: Eu, Gd, Tb, Dy, and Y), and heavy (HREY: Ho, $\mathrm{Er}, \mathrm{Tm}, \mathrm{Yb}$, and $\mathrm{Lu}$ ) [42]. After the normalization to the Upper Continental Crust (UCC) [43], three distribution types are identified: L-type (light-REY; LaN/LuN $>1$ ), M-type (medium-REY; $\mathrm{La}_{\mathrm{N}} / \mathrm{Sm}_{\mathrm{N}}<1$, $\mathrm{GdN}_{\mathrm{N}} / \mathrm{LuN}_{\mathrm{N}}>1$ ), and H-type (heavy REY; LaN/LuN < 1) [42].

The REY contents of the Mahe coals range from $100 \mu \mathrm{g} / \mathrm{g}$ to $336 \mu \mathrm{g} / \mathrm{g}$ as whole coal basis, with an average of $233 \mu \mathrm{g} / \mathrm{g}$ (Table 4). The Eu/Eu* value is from 0.78 to 1.02, with an average of 0.91 (Table 4). Three distribution types of REY are also present in the Mahe coal samples: L-type of MhC6a, M-type of $\mathrm{McC} 2$ and $\mathrm{Mc5b}$, and H-type of MhC5a, respectively (Figure 5). The MhC6a shows an M-H type REY distribution pattern. In coal, L-type REY pattern is of terrigenous origin; M-type REY pattern is probably attributed to REY supply by hydrothermal solutions; and H-type REY pattern was resulted from the circulation of HREE-bearing natural water and finally adsorbed by organic matter [42]. The L-type REY pattern of the sample MhC6a is also attributed to the terrigenous detrital input. Among the LTAs of the five coal samples, the McC6a has the highest content of kaolinite and mixed-layer I/S (illite) (57.3\%), following by Mh6b (39.3\%), Mh5a (28.7\%), Mh5b (21.1\%), and MhC2 (11.8\%) (Table 2). Kaolinite and mixed-layer I/S as lenses and thin beds were derived from the weathering products of the basalt from the Kangdian Upland [6]. The higher content of kaolinite and mixed-layer I/S (or illite) means that more terrigenous detrital input were received by the MhC6 coal during the peat mire accumulation than other coal seams. However, the lowest content of the kaolinite and mixed-layer I/S (illite) in $\mathrm{McC} 2$ suggests that the terrigenous detrital input has a less contribution to the mineral matter than the hydrothermal solution precipitation indicated by authigenic quartz and chamosite. Thus, the M-type REY pattern of MhC2 is mainly associated with the precipitation of the weathering Fe-Mg-rich solution of basalt. This is the similar situation for the sample MhC5a. The H-type REY pattern of MhC5a is attributed to its high content of organic matter (indicated by lowest ash yield $25.75 \%$, Table 1). Because organic matter in coal favors HREE brought by the circulation of natural water [44].

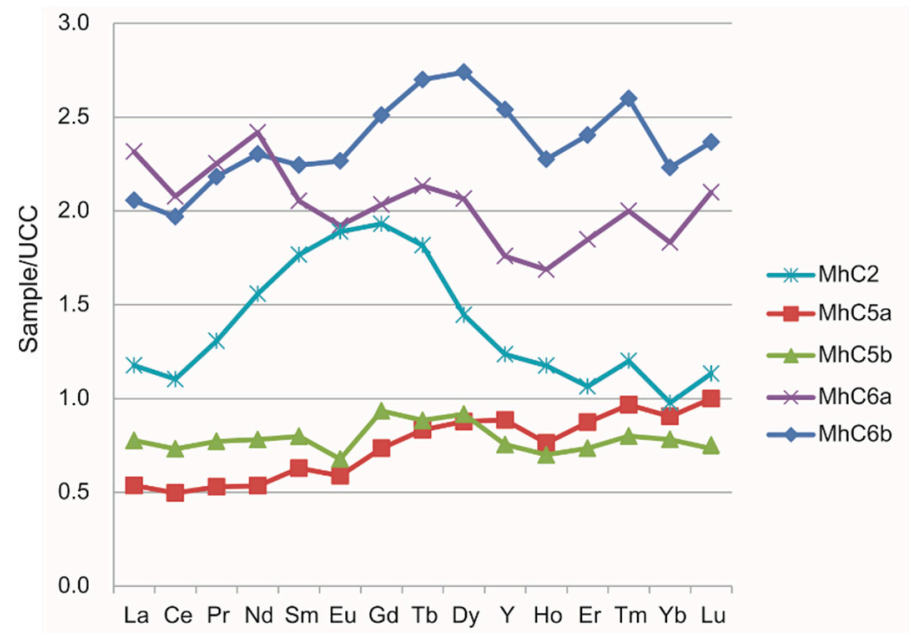

Figure 5. Distribution patterns of REY in the Mahe coal samples. REY are normalized by Upper Continental Crust (UCC) [43]. 
Table 4. Rare earth elements and yttrium (REY) concentrations and parameters in the Mahe coals, normalized to Upper Continental Crust [43].

\begin{tabular}{ccccccc}
\hline Samples & $\mathbf{R E Y}(\boldsymbol{\mu g} / \mathbf{g})$ & $\mathbf{L a}_{\mathbf{N}} / \mathbf{L} \mathbf{u}_{\mathbf{N}}$ & $\mathbf{L a}_{\mathbf{N}} / \mathbf{S} \mathbf{m}_{\mathbf{N}}$ & $\mathbf{G d}_{\mathbf{N}} / \mathbf{L} \mathbf{u}_{\mathbf{N}}$ & $\mathbf{C e} / \mathbf{C e} \mathbf{e}^{*}$ & $\mathbf{E u} / \mathbf{E u}$ \\
\hline $\mathrm{MhC2}$ & 212 & 1.04 & 0.67 & 1.70 & 0.89 & 1.02 \\
$\mathrm{MhC5a}$ & 100 & 0.54 & 0.85 & 0.73 & 0.93 & 0.86 \\
$\mathrm{MhC5b}$ & 128 & 1.06 & 0.97 & 1.27 & 0.94 & 0.78 \\
$\mathrm{MhC6a}$ & 358 & 1.10 & 1.13 & 0.97 & 0.91 & 0.94 \\
$\mathrm{MhC6b}$ & 366 & 0.87 & 0.92 & 1.06 & 0.93 & 0.95 \\
\hline
\end{tabular}

$\mathrm{Ce} / \mathrm{Ce}^{*}=2 \mathrm{Ce}_{\mathrm{N}} /\left(\mathrm{La}_{\mathrm{N}}+\mathrm{Pr}_{\mathrm{N}}\right) ; \mathrm{Eu} / \mathrm{Eu}^{*}=2 \mathrm{Eu}_{\mathrm{N}} /\left(\mathrm{Sm}_{\mathrm{N}}+\mathrm{Gd}_{\mathrm{N}}\right)$.

\section{Discussion: The Sources of Minerals in the Mahe Coals}

For the Late Permian coals from the eastern Yunnan (Figure 1) including the Xuanwei [3], Xinde [4], Taoshuping [6], and Changxing [26] mines, four mineral sources were identified: (i) Emeishan basalt (the weathering detrital residues or the weathering Fe-Mg-rich silicon solution); (ii) silicic/mafic volcanic ashes; (iii) Maokou limestone; and (iii) hydrothermal fluids/igneous invasion.

However, in the northeastern Yunnan (Figure 1), mineral sources of the Mahe coals are attributed to not only (i) Emeishan basalt; (ii) silicic volcanic ashes; and (iii) hydrothermal fluids, but also Emeishan silicic rock. The kaolinite and mixed-layer I/S occurring as lenses and thin beds were derived from the weathering detrital residues of the basalt. It is also supported by the elevated concentrations of Sc, V, Cr, Co, and $\mathrm{Ni}$ in the Mahe coals, because Emeishan basalt are high in these elements [38]. The abundant authigenic quartz and chamosite were precipitated from the weathering Fe-Mg-rich silicon solution of Emeishan basalt [6,45]. The presence of $\beta$-form quartz in the Mahe coals suggests an input of silicic volcanic ashes during the peat mire formation. However, calcite as veins in the Mahe coals may have been precipitated by circulation of Ca-bearing meteoric fluids [46].

The euhedral quartz (Figure 3B) and apatite (Figure 3H) in the Mahe coals could not be attributed to the three sources discussed above. Firstly, quartz and apatite could not be the terrigenous detrital input of the weathering basalt residues. Because no quartz and apatite exists in the Emeishan basalt of the Kangdian Upland, which is mainly comprised of clinopyroxene, olivine, plagioclase, basaltic glasses or microlite, and magnetite [47]. Secondly, the euhedral quartz is not precipitated by the weathering Fe-Mg-rich silicon solution of the basalt. The authigenic quartz is irregular in shape rather than a euhedral form. In addition, the authigenic quartz is smaller in size than the euhedral quartz (Figure 3A,B). Thirdly, the euhedral quartz and apatite are not attributed to the silicic volcanic ashes input. $\beta$-form quartz and apatite induced by the silicic volcanic ashes in the Late Permian coal from eastern Yunnan are much smaller in size (about 20-100 $\mu \mathrm{m}$ and less than $5 \mu \mathrm{m}$, respectively) $[3,4,6]$ than that of the euhedral quartz and apatite in the Mahe coals $(100-500 \mu \mathrm{m}$ and $220 \mathrm{um}$ in size, respectively) (Figure 3C,H).

In the Binchuan from the western Yunnan, the silicic rock occurring at the uppermost part of the basalt sequence means there were also small scale silicic igneous eruption after massive flood basalt eruption [48]. Since quartz and apatite are common in silicic rock rather than basalt, it is inferred that euhedral quartz and apatite in the Mahe coals are probably related to the Emeishan silicic rock. However, the silicic sources of the Mahe coals is close to the peat mire in the eastern Yunnan rather than the faraway Binchuan area (more than $400 \mathrm{~km}$ between Binchuan and Mahe mine) from western 
Yunnan. Because the frequent collision and friction suffered from the the long-distance transport from western Yunnan would have resulted in more rounded shape of quartz and apatite. Thus, the euhedral quartz and apatite indicate there was silicic rock input during the Mahe coal accumulation. This further implies that there has been silicic igneous eruption in eastern Yunnan Province.

Implication of $\mathrm{Eu} / \mathrm{Eu}^{*}$ value also supports a silicic rock detrital input in the Mahe coals. As shown in Table 5, the Mahe coals show a slight negative $\mathrm{Eu} / \mathrm{Eu}^{*}$ anomaly, whereas other coals from the Xinde, Xuanwei, and Taoshuping mines have no or slight positive $\mathrm{Eu} / \mathrm{Eu}^{*}$ anomaly. The $\mathrm{Eu} / \mathrm{Eu}^{*}$ anomaly in coal, which is usually inherited from the parent rocks, is frequently used as an indicator of the terrigenous detrital sources [44,49]. The Emeishan silicic rock has a strong negative $\mathrm{Eu} / \mathrm{Eu}^{*}$ anomaly with the value of 0.56 , whereas the basalt shows a positive $\mathrm{Eu} / \mathrm{Eu}^{*}$ anomaly with the value of 1.41 (Table 5). The detrital particles of silicic rock input in the Mahe coals resulted in a lower $\mathrm{Eu} / \mathrm{Eu}$ * value (0.91) of the Mahe coals than that of other Late Permian coals (1.04 of the Xinde coals, 0.99 of the Xuanwei coals, and 1.06 of the Taoshuping coals), in which the terrigenous detrital input was mainly derived from the weathering residue of basalt $[3,4,6]$.

Table 5. $\mathrm{Eu} / \mathrm{Eu}^{*}$ value, normalized to Upper Continental Crust (UCC)[43], in Late Permian coals from eastern Yunnan, and the Emeishan silicic rock and basalt.

\begin{tabular}{ccccccc}
\hline Eu/Eu* & Mahe & Xinde* $^{*}$ & Xuanwei* $^{*}$ & Taoshuping* & Silicic Rock* & Basalt* \\
\hline Range & $0.78-1.92$ & $0.80-1.19$ & $0.73-1.27$ & $0.77-1.25$ & - & - \\
Average & 0.91 & 1.04 & 0.99 & 1.06 & 0.56 & 1.41 \\
Number * & 5 & 9 & 6 & 17 & - & - \\
\hline
\end{tabular}

* Xinde from Dai et al. [4]; Xuanwei from Dai et al. [3]; Taoshuping from Wang et al. [6]; Silicic rock is rhyolite from Xu et al. [48]; basalt from Xiao et al. [38]. Number, sample number.

\section{Conclusions}

The Late Permian C2, C5a, C5b, C6a, and C6b coals from the Mahe mine are semianthracite with medium to high-ash yield and medium-high- to high-sulfur content. Minerals in the coals are mainly made up of quartz, chamosite, kaolinite, mixed-layer I/S, pyrite, and calcite, followed by anatase, dolomite, siderite, illite and marcasite. Compared with the Chinese average coals, the Mahe coals are high in Sc $(4.38 \mu \mathrm{g} / \mathrm{g}), \mathrm{V}(105 \mu \mathrm{g} / \mathrm{g}), \mathrm{Cr}(45.7 \mu \mathrm{g} / \mathrm{g}), \mathrm{Co}(19.0 \mu \mathrm{g} / \mathrm{g}), \mathrm{Ni}(29.8 \mu \mathrm{g} / \mathrm{g}), \mathrm{Cu}(70.4 \mu \mathrm{g} / \mathrm{g})$, $\mathrm{Ga}(14.9 \mu \mathrm{g} / \mathrm{g})$, and $\mathrm{Sn}(4.75 \mu \mathrm{g} / \mathrm{g})$. The mineralogical and geochemical characteristics of the Mahe coals are attributed to four factors including Emeishan basalt, Emeishan silicic rock, silicic volcanic ashes, and hydrothermal fluid. The euhedral quartz and apatite particles in the Mahe coals mean that they were derived from silicic rocks. In addition, this further implies that there has been silicic igneous eruption in the northeast of Yunnan.

\section{Acknowledgments}

This research was supported by the National Key Basic Research Program of China (No. 2014CB238900), the National Natural Science Foundation of China (No. 41202121), the Program for Changjiang Scholars and Innovative Research Team in University (IRT13099). The authors wish to thank Yiping Zhou and Xiaolin Song for their great supports to this study. 


\section{Author Contributions}

Xibo Wang conceived the overall experimental strategy and performed major elements measurement and microscopic experiments. Ruixue Wang, Jiangpeng Wei and Peipei Wang did the XRD and trace elements determination. Qiang Wei observed these samples using SEM-EDX. All authors participated in writing the manuscript.

\section{Conflicts of Interest}

The authors declare no conflict of interest.

\section{References}

1. Tian, L. Coal Combustion Emissions and Lung Cancer in Xuan Wei, China. Ph.D. Thesis, University of California, Berkeley, CA, USA, 2005.

2. Tian, L.; Dai, S.; Wang, J.; Huang, Y.; Ho, S.C.; Zhou, Y.; Lucas, D.; Koshland, C.P. Nanoquartz in Late Permian $\mathrm{C} 1$ coal and the high incidence of female lung cancer in the Pearl River Origin area: A retrospective cohort study. BMC Public Health 2008, 8, 398.

3. Dai, S.F.; Tian, L.W.; Chou, C.L.; Zhou, Y.P.; Zhang, M.Q.; Zhao, L.; Wang, J.M; Yang, Z.; Cao, H.Z.; Ren, D.Y. Mineralogical and compositional characteristics of Late Permian coals from an area of high lung cancer rate in Xuan Wei, Yunnan, China: Occurrence and origin of quartz and chamosite. Int. J. Coal Geol. 2008, 76, 318-327.

4. Dai, S.F.; Li, T.; Seredin, V.V.; Ward R.C.; Hower, J.C.; Zhou, Y,P.; Zhang, M.Q.; Song, X.L.; Song, W.J.; Zhao, C.L. Origin of minerals and elements in the Late Permian coals, tonsteins, and host rocks of the Xinde Mine, Xuanwei, eastern Yunnan, China. Int. J. Coal Geol. 2014, 121, 53-78.

5. Large, D.J.; Kelly, S.; Spiro, B.; Tian, L.; Shao, L.; Finkelman, R.; Zhang, M.; Somerfield, C.; Plint, S.; Ali, Y.; et al. Silica-volatile interaction and the geological cause of the Xuan Wei lung cancer epidemic. Environ. Sci. Technol. 2009, 43, 9016-9021.

6. Wang, X.; Dai, S.; Chou, C.-L.; Zhang, M.; Wang, J.; Song, X.; Wang, W.; Jiang, Y.; Zhou, Y.; Ren, D. Mineralogy and geochemistry of Late Permian coals from the Taoshuping Mine, Yunnan Province, China: Evidences for the sources of minerals. Int. J. Coal Geol. 2012, 96-97, 49-59.

7. Dai, S.; Wang, X.; Zhou, Y.; Hower, J.C.; Li, D.; Chen, W.M.; Zhu, X.W. Chemical and mineralogical compositions of silicic, mafic, and alkali tonsteins in the late Permian coals from the Songzao Coalfield, Chongqing. Southwest China. Chem. Geol. 2011, 282, 29-44.

8. Zhou, Y.; Bohor, B.F.; Ren, Y.L. Trace element geochemistry of altered volcanic ash layers (tonsteins) in Late Permian coal-bearing formations of eastern Yunnan and western Guizhou Province, China. Int. J. Coal Geol. 2000, 44, 305-324.

9. Dai, S.F.; Chou, C.L. Occurrence and origin of minerals in a chamosite-bearing coal of Late Permian age, Zhaotong, Yunnan, China. Am. Mineral. 2007, 92, 1253-1261.

10. Coal Geology Bureau of China. Sedimentary Environments and Coal Accumulation of Late Permian Coal Formation in Western Guizhou., Southern Sichuan and Eastern Yunnan, China; Chongqing University Press: Chongqing, China, 1996. (In Chinese) 
11. He, B.; Xu, Y.G.; Huang, X.L.; Luo, Z.Y.; Shi, Y.R.; Yang, Q.J.; Yu, S.Y. Age and duration of the Emeishan Flood volcanism, SW China: Geochemistry and SHRIMP zircon U-Pb dating of silicic ignimbrites, post volcanic Xuanwei Formation and clay tuff at Chaotian section. Earth Planet. Sci. Lett. 2007, 255, 306-323.

12. He, B.; Xu, Y.G.; Guan, J.P.; Zhong, Y.T. Paleokarst on the top of the Maokou Formation: Further evidence for domal crustal uplift prior to the Emeishan flood volcanism. Lithos 2010, 119, 1-9.

13. ASTM International. Test Method for Moisture in the Analysis Sample of Coal and Coke; ASTM D3173-11; ASTM International: West Conshohocken, PA, USA, 2011.

14. ASTM International. Test Method for Volatile Matter in the Analysis Sample of Coal and Coke; ASTM D3175-11; ASTM International: West Conshohocken, PA, USA, 2011.

15. ASTM International. Test Method for Ash in the Analysis Sample of Coal and Coke from Coal; ASTM D3174-11; ASTM International: West Conshohocken, PA, USA, 2011.

16. ASTM International. Test Methods for Total Sulfur in the Analysis Sample of Coal and Coke; ASTM D3177-02; ASTM International: West Conshohocken, PA, USA, 2011.

17. Ward, C.R.; Spears, D.A.; Booth, C.A.; Staton, I.; Gurba, L.W. Mineral matter and trace elements in coals of the Gunnedah Basin, NewSouth Wales, Australia. Int. J. Coal Geol. 1999, 40, 281-308.

18. Ward, C.R.; Matulis, C.E.; Taylor, J.C.; Dale, L.S. Quantification of mineral matter in the Argonne Premium coals using interactive Rietveld-based X-ray diffraction. Int. J. Coal Geol. 2001, 46, 67-82.

19. Ruan, C.-D.; Ward, C.R. Quantitative X-ray powder diffraction analysis of clay minerals in Australian coals using Rietveld methods. Appl. Clay Sci. 2002, 21, 227-240.

20. Dai, S.F.; Li, T.J.; Jiang, Y.F.; Ward, C.R.; Hower, J.C.; Sun, J.H.; Liu, J.J.; Song, H.J.; Wei, J.P.; Li, Q.Q.; et al. Mineralogical and geochemical compositions of the Pennsylvanian coal in the Hailiushu Mine, Daqingshan Coalfield, Inner Mongolia, China: Implications of sediment-source region and acid hydrothermal solutions. Int. J. Coal Geol. 2015, 137, 92-110.

21. Dai, S.F.; Hower, J.C.; Ward, C.R.; Guo, W.M.; Song, H.J.; O’Keefe, J.M.K.; Xie, P.P.; Hood, M.M.; Yan, X.Y. Elements and phosphorus minerals in the middle Jurassic inertinite-rich coals of the Muli Coalfield on the Tibetan Plateau. Int. J. Coal Geol. 2015, 144-145, 23-47.

22. ASTM International. Standard Test Method for Total Fluorine in Coal and Coke by Pyrohydrolytic Extraction and Ion Selective Electrode or Ion Chromatograph Methods; ASTM Standard D5987-96 (2002) (Reapproved 2007); ASTM International: West Conshohocken, PA, USA, 2011.

23. ASTM International. Standard Classification of Coals by Rank; ASTM D388-12; ASTM International: West Conshohocken, PA, USA, 2012.

24. Standardization Administration of the People's Republic of China. Classification for Quality of Coal. Part 1: Ash, 2010; Chinese Standard GB/T 15224, 1-2010; Standardization Administration of the People's Republic of China: Beijing, China. (In Chinese)

25. Standardization Administration of the People's Republic of China. Classification for Quality of Coal. Part 2: Sulfur, 2010; Chinese Standard GB/T 15224, 2-2010; Standardization Administration of the People's Republic of China: Beijing, China. (In Chinese)

26. Wang, X.; Zhang, M.; Zhang, W.; Wang, J.; Zhou, Y.; Song, X.; Li, T.; Li, X.; Liu, H.; Zhao, L. Occurrence and origins of minerals in mixed-layer illite/smectite-rich coals of the Late Permian age from the Changxing Mine, eastern Yunnan, China. Int. J. Coal Geol. 2012, 102, 26-34. 
27. Tang, X.Y.; Huang, W.H. Trace Elements in Chinese Coal; Business Press: Beijing, China, 2004. (In Chinese)

28. Faraj, B.S.M.; Fielding, C.R.; Mackinnon, D.R. Cleat mineralization of Upper Permian Baralaba/Rangal Coal Measures, Bowen Basin, Australia. In Coalbed Methane and Coal Geology; Gayer, R., Harris, I., Eds.; Geological Society Special Publication: London, UK, 1996; Volume 109, pp. 151-164.

29. Permana, A.; Ward, C.R.; Li, Z.; Gurba, L.W. Distribution and origin of minerals in high-rank coals of the South Walker Creek area, Bowen Basin, Australia. Int. J. Coal Geol. 2013, 116-167, 185-207.

30. Vassilev, S.V.; Kitano, K.; Vassileva, C.G. Some relationships between coal rank and chemical and mineral composition. Fuel 1996, 75, 1537-1542.

31. Wang, X.B.; Jiang, Y.F.; Zhou, G.Q.; Wang, P.P.; Wang, R.X.; Zhao, L.; Chou, C.-L. Behavior of minerals and trace elements during natural coking: A case study of an intruded bituminous coal in the Shuoli mine, Anhui Province, China. Energy Fuels 2015, doi:10.1021/acs. energyfuels.5b00634.

32. Ward, C.R. Analysis and significance of mineral matter in coal seams. Int. J. Coal Geol. 2002, 50, 135-168.

33. Dai, S.F.; Seredin, V.V.; Ward, C.R.; Hower, J.C.; Xing, Y.W.; Zhang, W.G.; Song, W.J.; Wang, P.P. Enrichment of U-Se-Mo-Re-V in coals preserved within marine carbonate successions: Geochemical and mineralogical data from the Late Permian Guiding Coalfield, Guizhou, China. Miner. Deposita 2015, 50, 159-186.

34. Bouška, V.; Pešek, J.; Sýkorová, I. Probable modes of occurrence of chemical elements in coal. Acta Mont. Ser. B Fuel Carbon Miner. Process. 2000, 10, 53-90.

35. Dai, S.F.; Yang, J.Y.; Ward, C.R.; Hower, J.C.; Liu, H.D.; Garrison, T.M.; French, D.; O'Keefe, J.M.K. Geochemical and mineralogical evidence for a coal-hosted uranium deposit in the Yili Basin, Xinjiang, northwestern China. Ore Geol. Rev. 2015, 70, 1-30.

36. Chou, C.-L. Sulfur in coals: A review of geochemistry and origins. Int. J. Coal Geol. 2012, 100, 1-13.

37. Dai, S.F.; Ren, D.Y.; Chou, C.L.; Finkelman, R.B.; Seredin, V.V.; Zhou, Y.P. Geochemistry of trace elements in Chinese coals: A review of abundances, genetic types, impacts on human health, and industrial utilization. Int. J. Coal Geol. 2012, 94, 3-21.

38. Xiao, L.; Xu, Y.; Mei, H.; Zheng, Y.; He, B.; Pirajno, F. Distinct mantle sources of low-Ti and high-Ti basalts from the western Emeishan large igneous province, SW China: Implications for plume-lithosphere interaction. Earth Planet. Sci. Lett. 2004, 228, 525-546.

39. Dai, S.F; Zeng, R.S; Sun, Y.Z. Enrichment of arsenic, antimony, mercury, and thallium in a late Permian anthracite from Xingren, Guizhou, southwest China. Int. J. Coal Geol. 2006, 66, 217-226.

40. Hower, J.C.; Campbell, J.L.; Teesdale, W.J.; Nejedly, Z.; Robertson, J.D. Scanning proton microprobe analysis of mercury and other trace elements in Fe-sulfides from a Kentucky coal. Int. J. Coal Geol. 2008, 75, 88-92.

41. Yudovich, Ya.E.; Ketris, M.P. Mercury in coal: A review. Part 1. Geochemistry. Int. J. Coal Geol. 2005, 62, 107-134.

42. Seredin, V.V.; Dai, S. Coal deposits as a potential alternative source for lanthanides and yttrium. Int. J. Coal Geol. 2012, 94, 67-93. 
43. Taylor, S.R.; McLennan, S.M. The Continental Crust: Its Composition and Evolution; Blackwell: Oxford, UK, 1985; p. 312.

44. Seredin, V.; Finkelman, R. Metalliferous coals: A review of the main genetic and geochemical types. Int. J. Coal Geol. 2008, 76, 253-289.

45. Ren, D.Y. Mineral matter in coal. In Coal Petrology of China; Han, D.X., Ed.; Publishing House of China University of Mining and Technology: Xuzhou, China, 1996; pp. 67-78.

46. Kolker, A.; Chou, C.-L. Cleat-filling calcite in Illinois Basin coals: Trace element evidence for meteoric fluid migration in a coal basin. J. Geol. 1994, 102, 111-116.

47. Xu, Y.G.; Chung, S.L.; Jahn, B.M.; Wu, G.Y. Petrologic and geochemical constraints on the petrogenesis of Permian-Triassic Emeishan flood basalts in southwestern China. Lithos 2001, 58, $145-168$.

48. Xu, Y.G.; Chung, S.L.; Shao, H.; He, B. Silicic magmas from the Emeishan large igneous province, southwest China: Petrogenesis and their link with the end-Guadalupian biological crisis. Lithos 2010, 119, 47-60.

49. Goodarzi, F.; Sanei, H.; Stasiuk, L.D.; Bagheri-Sadeghi, H.; Reyes, J. A preliminary study of mineralogy and geochemistry of four coal samples from northern Iran. Int. J. Coal Geol. 2006, 65, $35-50$.

(C) 2015 by the authors; licensee MDPI, Basel, Switzerland. This article is an open access article distributed under the terms and conditions of the Creative Commons Attribution license (http://creativecommons.org/licenses/by/4.0/). 